\title{
STUDIES ON ENTEROHAEMORRHAGIC ESCHERICHIA COLI (EHCE) STRAINS NON 0157:H7 IN CHICKEN WITH REGARD TO ANTIBIOTIC RESISTANCE GENE ON PLASMID
}

\author{
SOAD A. NASEF ${ }^{1}$; AMAL S. EL OKSH ${ }^{2}$ and GHADA A. IBRAHIM ${ }^{3}$ \\ ${ }^{1}$ Chief Researcher, RLQP, Dokki, Poultry Diseases \\ ${ }^{2}$ Researcher, Bacteriology Department, RLQP, Zagazig Branch, Bacteriology \\ ${ }^{3}$ Researcher, Bacteriology Department, AHRI, Ismailia Branch, Bacteriology
}

Received: 8 March 2017; $\quad$ Accepted: 30 March 2017

\begin{abstract}
Shiga-toxin-producing Escherichia coli (STEC) are the most important recently emerged group of food-borne pathogens. Among fifty EHEC strains, thirty strains were found as non O157 EHEC (60\%) by serotyping. Also the highest incidence of $\mathrm{O} 26$ and $\mathrm{O} 111$ were $16 \%$ and 14\%, respectively, meanwhile the lowest was of O128 (2\%). Antibiotic resistance profiles for these strains showed $100 \%$ resistance to: sulfamethoxazole, Trimethoprime, chlormphencal, colistin, gentamycin and tetracycline. However, they showed $85 \%$ resistance to streptomycin and doxycycline, $80 \%$ resistance to cefotraxone while their resistance for amoxicillin clavulanic acid was $75 \%$. PCR examination for twenty strains of EHEC non O157 revealed stx 1 gene in $45 \%$, st $x 2$ in $65 \%$ while hly in $80 \%$ of the examined strains. Antimicrobial resistance genes for these strains confirmed that sulI, aadA and blaTEM resistance genes were detected in percentages of $85 \%, 75 \%$ and $60 \%$, respectively. Recommendation for minimizing an excessive use of antibiotics in the veterinary field and periodically use of different antibiotics could overcome the problem of increased bacterial resistance.
\end{abstract}

Key words: EHEC, non O157, resistance, genes, virulence, antibiotic, serotyping.

\section{INTRODUCTION}

Chicken meat is one of the most popular foods among population. However, the epidemiology and prevalence of EHEC strains in chicken meat is essentially unknown. Enterohemorrhagic Escherichia coli (EHEC) is considered recently as one of important emerged groups of food-borne pathogens. Although E. coli $\mathrm{O} 157: \mathrm{H} 7$ is currently the most common EHEC strains in many regions of the world (Armstrong et al., 1996) but serotypes O103, O26, O104,O111, O 113,O 128, O5 and O145 (which are now usually referred to as non-O157 EHEC) constituted also a serious threat to public health (Bettelheim,1996). They characterized by their specific virulence factors and its ability to produce potent cytotoxins (verotoxins). All strains produce hemolysin (which is encoded by hlyA) (Schmidt et al., 1994) and at least one Shiga-like toxin (encoded by stx 1 or stx 2 ) (O’Brien et al., 1987). Shiga - like toxins have similar biological activities including cytotoxicity to Vero and HeLa cells, but they are different immunologically (Law, 2000).

Corresponding author: Dr. AMAL S. EL OKSH

E-mail address: saidamal19@yahoo.com

Present address: Researcher, Bacteriology Department, RLQP, Zagazig Branch, Bacteriology
Antimicrobials are routinely used for disease prevention and growth promotion in poultry production however, they are not recommended for treating EHEC O157:H7 infection because antimicrobials may lyse bacterial cell walls, thereby liberating Shiga toxins (Wong et al., 2000 and Hedican et al., 2009), and/or cause increased expression of Shiga toxin genes in vivo (Zhang et al., 2000).

Although EHEC infections are not aggressively treated with antimicrobial therapy and many isolates are susceptible to numerous antimicrobials, recent reports indicate that antimicrobial resistance of EHEC is on the rise (Farina et al., 1996; Galland et al. 2001 and Schroeder et al., 2002).Moreover, it is proven that repeated sublethal exposure to antibacterial agents not only promotes adaptative resistance but also confers decreased sensitivity to antibiotics (Braoudaki and Hilton, 2003). This practice leads to a selection of antimicrobial resistance among commensals in the intestinal tracts of chicken, which poses a public health threat (Witte, 1998).

Ideally, PCR-based detection methods are rapid and sensitive without need for extensive sample preparations. Large plasmids resembling carried the genetic information for most non-O157 EHEC strains which is responsible for the so-called enterohaemolytic phenotype. (Schmidt et al., 1995). 
Due to the fact of definite zoonotic origin and pathogenic STEC/EHEC group. This paper will review the recentfinding on the most virulence factors of EHEC, trying to seek out what makes a STEC, an EHEC highly pathogenic to poultry production and evaluation of antibiotic resistance properties in EHEC serogroups isolated from chicken meat (Momtaz and Jamshidi, 2013).

\section{MATERIALS AND METHODS}

\section{Bacterial strains}

A total of 50 EHEC strains that were recovered from chicken and were collected from different sources in Sharkia province, Egypt. The majority of strains included in the present study had been obtained in previously published studies (Blanco et al., 2001; Blanco et al., 2003 and Blanco et al., 2004) and the procedures for their isolation were described in detail in those studies.

\section{Serotyping}

EHEC strains were serotyped by slide agglutination test with commercially available polyvalent and monovalent anti $\mathrm{E}$ coli $\mathrm{O}$ and $\mathrm{K}$ sera (Test Sera Enteroclon, Anti -Coli, SIFIN Berlin, Germany).

\section{Antimicrobial susceptibility testing}

The susceptibility of identified EHEC strains to a panel of ten commonly used antimicrobial agents was performed by the standard Kirby-Bauer disc diffusion method (Bauer et al., 1966) and the results were interpreted according to the criteria recommended by the Clinical and Laboratory Standards Institute for antimicrobial susceptibility testing (CLSI, 2011) Isolates resistant to three or more antibiotics were classified as MDR strains.

\section{Molecular detection of antibiotic resistance and virulence genes}

Plasmid DNA from 10 MDR EHEC strains was isolated using QIAprep Spin Miniprep Kit (QIAGEN $\mathrm{GmbH}$, Hilden, Germany). Screening for the presence of some antibiotic resistance and virulence plasmidassociated genes was carried out by PCR amplifications using specific primers and different cycling conditions as previously described by (Clark et al., 1999; Colom et al., 2003; Ewers et al., 2007 and Santos et al., 2014). The PCR products were tested for positive amplification by agarose gel electrophoresis (Sambrook et al., 1989). For each PCR experiment, appropriate positive and negative controls were included. The primer sequence from Metabion (Germany) of virulent and resistance genes and the amplification cycling conditions are listed in tables $(1 \& 2)$.

Table1: Oligonucleotide primer sequences of virulence and antibiotic resistance genes of E.coli.

\begin{tabular}{|c|c|c|c|}
\hline Target gene & & Primer sequence (5'-3') & References \\
\hline \multirow{2}{*}{ Stx 1} & $\mathrm{~F}$ & CAGTTAATGTGGTGGCGAAG & \multirow{2}{*}{ Sahilah et al., 2010} \\
\hline & $\mathrm{R}$ & CTGTCACAGTAACAACCGT & \\
\hline \multirow{2}{*}{ Stx 2} & $\mathrm{~F}$ & CCATGACAACGGACAGCAGTT & \multirow{2}{*}{ Dipineto et al., 2006} \\
\hline & $\mathrm{R}$ & CCTGTCAACTGAGCAGCACTTTG & \\
\hline \multirow{2}{*}{ hly } & $\mathrm{F}$ & AACAAGGATAAGCACTGTTCTGGCT & \multirow{2}{*}{ Piva et al., 2003} \\
\hline & $\mathrm{R}$ & ACCATATAAGCGGTCATTCCCGTCA & \\
\hline \multirow{2}{*}{ sulI } & $\mathrm{F}$ & CGG CGT GGG CTA CCT GAA CG & \multirow[t]{2}{*}{ Kerrn et al., 2002} \\
\hline & $\mathrm{R}$ & GCC GAT CGC GTG AAG TTC CG & \\
\hline \multirow{2}{*}{$\operatorname{aad} \mathrm{A} 1$} & $\mathrm{~F}$ & TGATTTGCTGGTTACGGTGAC & \multirow[t]{2}{*}{ Clark et al., 1999} \\
\hline & $\mathrm{R}$ & CGCTATGTTCTCTTGCTTTTG & \\
\hline \multirow{2}{*}{ blaTEM } & $\mathrm{F}$ & ATCAGCAATAAACCAGC & \multirow{2}{*}{ Colom et al., 2003} \\
\hline & $\mathrm{R}$ & CCCCGAAGAACGTTTTC & \\
\hline
\end{tabular}

Table 2: Cycling conditions and predicted sizes of PCR products for virulence and antibiotic resistance genes.

\begin{tabular}{|c|c|c|c|c|c|c|c|}
\hline \multirow{2}{*}{$\begin{array}{c}\text { Target } \\
\text { gene }\end{array}$} & \multirow{2}{*}{$\begin{array}{c}\text { Initial } \\
\text { denaturation } \\
{ }^{\circ} \mathrm{C} / \mathrm{min}\end{array}$} & \multirow[b]{2}{*}{ Cycle } & \multicolumn{3}{|c|}{ Actual cycles ${ }^{\circ} \mathrm{C} / \mathrm{sec}$} & \multirow{2}{*}{$\begin{array}{c}\text { Final } \\
\text { extention } \\
{ }^{\circ} \mathrm{C} / \mathrm{min}\end{array}$} & \multirow{2}{*}{$\begin{array}{l}\text { Amplified } \\
\text { product Size } \\
\text { (bp) }\end{array}$} \\
\hline & & & Denaturation & Annealing & Extension & & \\
\hline Stx 1 & $94 / 7$ & 94 & $94 / 30$ & $51 / 30$ & $72 / 30$ & $72 / 7$ & 180 \\
\hline Stx 2 & $94 / 10$ & 94 & $94 / 60$ & $58 / 60$ & $72 / 60$ & $72 / 10$ & 779 \\
\hline hly & $94 / 15$ & 94 & $94 / 60$ & $60 / 60$ & $72 / 90$ & $72 / 12$ & 1177 \\
\hline sulI & $94 / 5$ & 30 & $94 / 15$ & $69 / 30$ & $72 / 60$ & $72 / 7$ & 443 \\
\hline $\operatorname{aad} \mathrm{A} 1$ & $95 / 10$ & 30 & $94 / 30$ & $60 / 30$ & $72 / 30$ & $72 / 10$ & 284 \\
\hline bla TEM & $94 / 3$ & 32 & $94 / 30$ & $54 / 30$ & $72 / 60$ & $72 / 10$ & 516 \\
\hline
\end{tabular}




\section{RESULTS}

This study was done on fifty chicken E.coli strains isolated from avian origin as shown in Table 3, thirty five $(70 \%)$ strains were confirmed to be EHEC positive, also there were significant differences between the presence of attaching and effacing E.coli EPEC and EHEC subgroups in strains. Among the 35 EHEC included in this study, $5(10 \%)$ strains were serotyped as $\mathrm{O} 157: \mathrm{H} 7$ and $30(60 \%)$ non-O157. NonO157 EHEC strains were belonged to 8 different $\mathrm{O}: \mathrm{H}$ serotypes $\quad(\mathrm{O} 26: \mathrm{H}-, \quad \mathrm{O} 111: \mathrm{H}-, \mathrm{O} \quad$ 103:H3,O104, O145,O5,O113,O128). Based on the results, O26 $(16 \%)$ and $0111(14 \%)$ were of high incidence ratio among serogroups whereas $\mathrm{O} 128$ had the lowest incidence in EHEC strains $2 \%$.

Table 4 shows the distribution of virulence factors of non-O157EHEC strains. All of the EHEC-positive samples had stx 1 , stx 2 , and hly virulence genes with significant differences as shown in Table 5.

The antibiotic resistance profiles of the thirty nonO157 strains were significantly different with respect to the levels of resistance of $E$. coli to the tested antibiotics. Non-O157 EHEC serogroups demonstrated high rates $(100 \%)$ for sulfamethoxazole, trimethoprim, chlorumpheneol, colistin, gentamycin and tetracycline while $85 \%$ for streptomycin, doxycycline, $80 \%$ for cefotraxone and $75 \%$ for amoxicillin clavulanic acid.

Phenotypic resistance of non-O157 to amoxicillinclavulanic acid, sulfamethoxazole- trimethoprim and streptomycin antibiotics could be explained by the presence of blaTEM, sulI and aadA resistance genes among the tested strains $(60 \%, 85 \%$ and $75 \%)$, respectively.

The frequencies and combinations of virulence genes carried on plasmid (stx 1 , stx 2 and hly) of twenty nonO157 EHEC strains were assessed. Among the detected virulence genes, st $x 1$ and st $x 2$ were the most prevalent gene ( $45 \%$ and $65 \%$ ), followed by hlygene (80\%) fig. (1).

Finally, characterization of the selected non-O157 EHEC according to their serotypes, virulence potential and corresponding antibiotic resistance pattern were shown in table (5). It was demonstrated that MDR E. Coli serovars possessed at least two virulence genes accompanied by attendance of antibiotic resistance genes. The co-occurrence of these concerning trends confirmed that the acquisition of antimicrobial resistance by $E$. coli has been accompanied by increased virulence.

Table 3: Prevalence of detected serotypes based on total number of E.coli isolates.

\begin{tabular}{|c|c|c|c|}
\hline Types of E.coli strains & Serotypes & & \\
\hline \multirow{3}{*}{ EPEC } & $\mathrm{O} 2: \mathrm{H} 6$ & $12 \%(6)$ & \multirow{3}{*}{$24 \%(12)$} \\
\hline & $\mathrm{O} 1: \mathrm{H} 7$ & $8 \%(4)$ & \\
\hline & O127:H6 & $4 \%(2)$ & \\
\hline \multirow{9}{*}{ EHEC } & O26:H11 & $16 \%(8)$ & \multirow{8}{*}{$60 \%(30)$} \\
\hline & O111:H4 & $14 \%(7)$ & \\
\hline & O103:H2 & $6 \%(3)$ & \\
\hline & $\mathrm{O} 104$ & $8 \%(4)$ & \\
\hline & O 145 & $6 \%(3)$ & \\
\hline & $\mathrm{O} 5$ & $4 \%(2)$ & \\
\hline & O 113 & $4 \%(2)$ & \\
\hline & O128 & $2 \%(1)$ & \\
\hline & O157:H7 & \multicolumn{2}{|c|}{$10 \%(5)$} \\
\hline Untypable & \multicolumn{3}{|c|}{$6 \%(3)$} \\
\hline Total & \multicolumn{3}{|c|}{$100 \%(50)$} \\
\hline
\end{tabular}

Table 4: The prevalence of virulence genes and antibiotic resistance genes among examained EHEC.

\begin{tabular}{|c|c|c|}
\hline \multicolumn{2}{|c|}{ Genes } & \multirow{2}{*}{$\frac{\text { \% No. of isolate strains }}{45 \%(9 / 20)}$} \\
\hline Virulence genes & Stx 1 & \\
\hline & Stx 2 & $65 \%(13 / 20)$ \\
\hline & Hly & $80 \%(16 / 20)$ \\
\hline \multirow[t]{3}{*}{ Resistance genes } & Sul I & $85 \%(17 / 20)$ \\
\hline & $\operatorname{aad\mathrm {A}1}$ & $75 \%(15 / 20)$ \\
\hline & blaTEM & $60 \%(20 / 20)$ \\
\hline
\end{tabular}



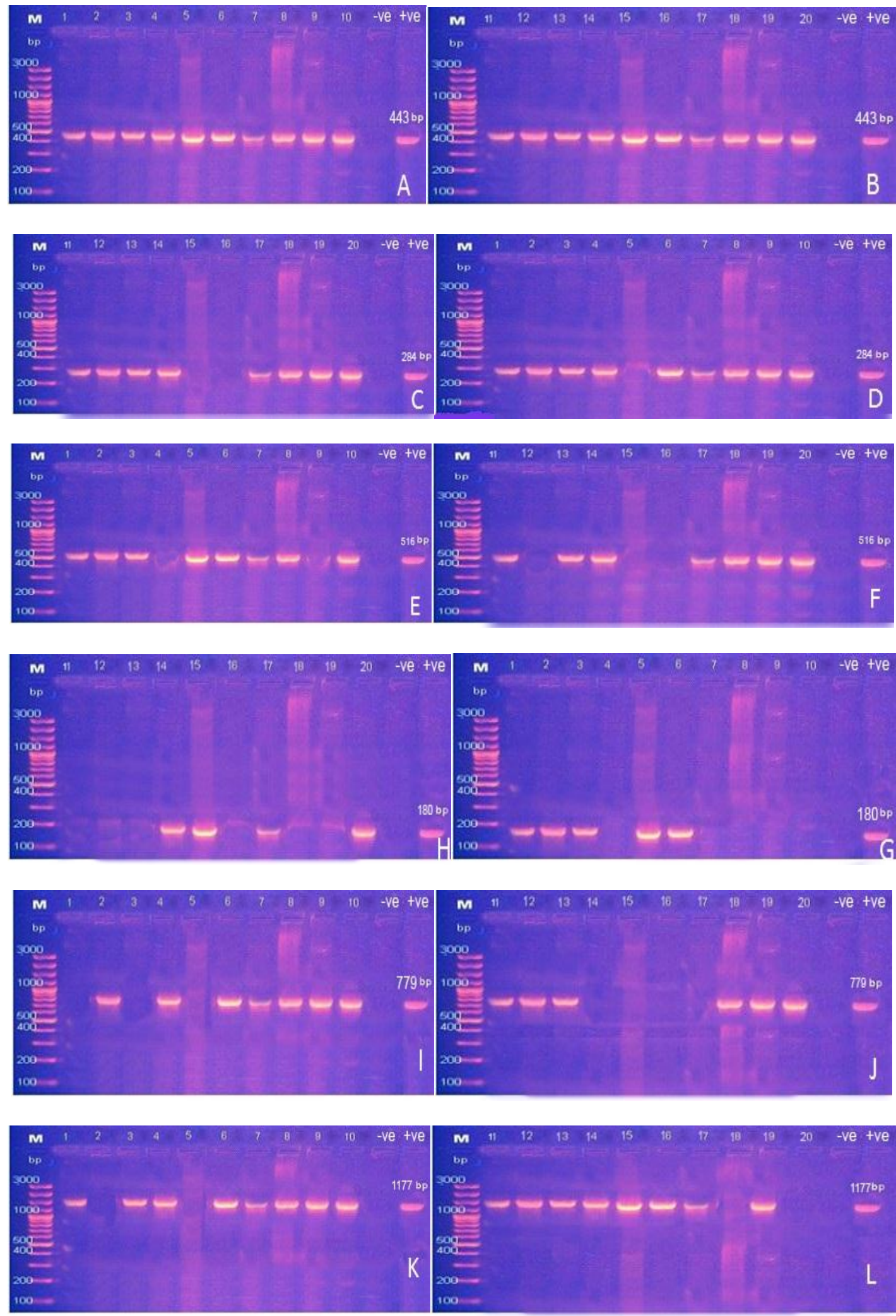

Fig. (1): Shows agarose gel electrophoresis of PCR amplified products of (A,B): sulI, (C,D):aadA1, (E,F) blaTEM resistant genes, $(\mathrm{G}, \mathrm{H}):$ stx $1,(\mathrm{I}, \mathrm{J}): s t x 2$ and $(\mathrm{K}, \mathrm{L})$ : hly virulence genes. Lane M: DNA molecular size marker (100 bp), lanes 1-20: E.coli isolates, lane (+ve): positive control and lane (-ve): negative control. The size in base pairs (bp) of each PCR product is indicated on the right of the bands 
Table 5: Resistance profiles and genotypic characterization of some virulence and antibiotic resistance genes of EHEC strains on their plasmid.

\begin{tabular}{|c|c|c|c|c|c|c|c|c|}
\hline \multirow{3}{*}{ ID } & \multirow{3}{*}{$\begin{array}{c}E . \text { coli } \\
\text { serotype }\end{array}$} & \multirow{3}{*}{ Resistance profile } & \multicolumn{6}{|c|}{ Genotypic characterization } \\
\hline & & & \multicolumn{3}{|c|}{ Virulence genes } & \multicolumn{3}{|c|}{$\begin{array}{c}\begin{array}{c}\text { Antibiotic resistance } \\
\text { genes }\end{array} \\
\end{array}$} \\
\hline & & & Stx1 & Stx2 & hly & sulI & $\operatorname{aadA1}$ & bla TEM \\
\hline 1 & $\mathrm{O} 26$ & SXT,CIP,AMC,CRO,S,TE,DO,C, CT, CN & + & - & + & + & + & + \\
\hline 2 & $\mathrm{O} 111$ & SXT,CIP,AMC,CRO,S,TE,DO,C, CT, CN & + & + & - & + & + & + \\
\hline 3 & $\mathrm{O} 103$ & SXT,CIP,AMC,S,TE,DO,C, CT, CN & + & - & + & + & + & + \\
\hline 4 & $\mathrm{O} 145$ & SXT,CIP, CRO,S,TE,DO,C, CT, CN & - & + & + & + & + & - \\
\hline 5 & $\mathrm{O} 111$ & SXT,CIP,AMC, TE,DO,C, CT, CN & + & + & - & + & - & + \\
\hline 6 & $\mathrm{O} 103$ & SXT,CIP,AMC,CRO,S,TE,DO,C, CT, CN & + & - & + & + & + & + \\
\hline 7 & $\mathrm{O} 26$ & SXT,CIP,AMC,CRO,S,TE,C, CT, CN & - & + & + & + & + & + \\
\hline 8 & $\mathrm{O} 145$ & SXT,CIP,AMC,CRO,S,TE,C, CT, CN & - & + & + & + & + & + \\
\hline 9 & $\mathrm{O} 26$ & SXT,CIP,CRO,S,TE,DO,C, CT, CN & - & + & + & + & + & - \\
\hline 10 & $\mathrm{O} 104$ & SXT,CIP,AMC,CRO,S,TE,DO,C, CT, CN & - & + & + & + & + & + \\
\hline 11 & $\mathrm{O} 5$ & SXT,CIP,AMC,S,TE,DO,C, CT, CN & - & + & + & + & + & + \\
\hline 12 & $\mathrm{O} 26$ & SXT,CIP,CRO,S,TE,DO,C, CT, CN & - & + & + & + & + & - \\
\hline 13 & $\mathrm{O} 113$ & $\begin{array}{l}\text { SXT,CIP,AMC,CRO,S,TE,DO,C, CT, CN } \\
\end{array}$ & - & + & + & + & + & + \\
\hline 14 & $\mathrm{O} 111$ & SXT,CIP,AMC,CRO,S,TE,C, CT, CN & + & - & + & + & + & + \\
\hline 15 & $\mathrm{O5}$ & SXT,CIP, CRO, TE,DO,C, CT, CN & + & - & + & + & - & - \\
\hline 16 & $\mathrm{O} 26$ & SXT,CIP, CRO, TE,DO,C, CT, CN & - & - & + & + & - & - \\
\hline 17 & $\mathrm{O} 104$ & SXT,CIP,AMC,S,TE,DO,C, CT, CN & + & - & + & + & + & + \\
\hline 18 & $\mathrm{O} 111$ & SXT,CIP,AMC,CRO,S,TE,DO,C, CT, CN & - & + & - & + & + & + \\
\hline 19 & $\mathrm{O} 26$ & SXT,AMC,CRO,S,TE,DO,C, CT, CN & - & + & + & + & + & + \\
\hline 20 & $\mathrm{O} 128$ & SXT,AMC,CRO,S,TE,DO,C, CT, CN & + & + & - & + & + & + \\
\hline
\end{tabular}

\section{DISCUSSION}

E.coli strains that cause entric infections are generally called diarrheagenic E.coli strains, and their pathogenesis is associated with a number of virulence attributes which vary according to pathotypes (Vidal et al., 2005). Currently, Diarrheagenic E.coli strains are classified into 6 pathotypes based on their distinct virulence determinants and pathogenic features, including Enterohemorrhagic E.coli (EHEC) that produceshiga-like toxins (Xia et al., 2010).

In this recent investigation, high recovered rate of EHEC strains $(70 \%)$ was recorded. Similar results were reported by (Lyhs et al., 2012; Eid and Erfan, 2013 and Peer et al., 2013) where E.coli was isolated in percentage of $94.5 \%, 80 \%$ and $84 \%$, respectively. Serotyping of EHEC strains confirmed the identification of $\mathrm{O} 157(10 \%)$ and non $\mathrm{O} 157$ serotypes $(60 \%)$. The non-O157 STEC serotypes were: O26 (16\%), O103 (6\%), O111 (14\%), O145 (6\%), $\mathrm{O} 5(4 \%), \mathrm{O} 113(4 \%), \mathrm{O} 128(2 \%)$ and $\mathrm{O} 104(8 \%)$. This result was in agreement with that recorded by (Hedican et al., 2009). However, another study in Korea showed that $(41$ / 900) from poultry samples were $E$. coli positive and non $\mathrm{O} 157$ serogroups were included in a percentage of $4.6 \%$ (Lee et al., 2009).

Because of the high indiscriminate use of antibiotics, especially in veterinary medicine, antibiotic resistance against most effective antibiotics was recorded. Several recent studies have documented antibiotic resistance especially among non-O157 EHEC (Farina et al., 1996; Horii et al., 1998; Galland et al., 2001 and Khan et al., 2002). This study is matching with our study which recorded high levels of resistance for some antimicrobial agents (sulfamethoxazole- trimethoprim, cholorumphenicol, colistin, gentamycin, tetracycline). Likewise, higher resistance rates have been reported for avian $E$. coli isolates to tetracycline $(100 \%)$ in Brazil (Lima-filho et al., 2013) and 84\% in Korea (Kim et al., 2007). Meanwhile, streptomycin, doxycycline and amoxicillin clavulanic acid antibiotics rates were $(70 \%, 70 \%$ and $75 \%)$, respectively, while doxycycline was recorded in another study in Egypt (51\%) (Eloksh, 2014).

The increased prevalence of resistance of E.coli isolates to these antibiotics is due to their regular usage in poultry industry for control of pathogenic avain colibacillosis in many districts in Egypt because of their low cost and availability. Also, it would seem that the discrepancies in the rate of E.coli resistance among different countries are due to differences in the level of dependence on antimicrobial usage and management practices in poultry production as well as variations in legislation guiding the use of antimicrobials from region to region. Therefore, non- 
O157 EHEC strains could be a potential reservoir of antimicrobial resistance genes.

As shown in figure (1), the highest incidence of antimicrobial resistance genes was for sul1 (100\%), followed by aadA1 (85\%), blaTEM (75\%), however some researchers in Iran detected these genes in percentage of $64.63 \%$ and $62.19 \%$, respectively. (Momtaz and Jamshidi, 2013).

While the serogroups are important for determining potential pathogens, the presence of virulence attributes, such as st 1 , stx 2 and $h l y$, are important parameters for pathogenicity of the strains. In addition, the virulence factors associated with these strains are linked to plasmids which detected by PCR. Consequently, they are likely to be subjected to horizontal gene transfer between the species as exhibited by dissemination of plasmids (Magwedere et al., 2013).

In prevalence of virulence genes (stx 1 and st $x 2)$ in the present study were $45 \%$ and $65 \%$, respectively whereas nine only out of 987 from poultry samples were positive for the same genes (Lukásová et al., 2004).

Boerlin et al. (1999) found non-O157 EHEC serotypes O26, O103, O111, and O145 expressing stx2 gene concluding that this makes the organism significantly more likely to cause serious disease, while Friedrich et al. (2002) found that of 87 isolates of non-O157 (including O26, O103, O121, and O145) harbored st $x 2$ gene.

Hemolysin ( $h l y$ ) gene is also one of important virulence factors (Gyles, 2006) which is more common in EHEC strains and in this study recorded in $80 \%$ of total non-O157 EHEC strains. It is widely distributed among non-O157 strains and could cause lysis of red blood cells in vitro. Approximately $90 \%$ of all EHEC strains possess genes encoding hemolysin (Kilic et al., 2007)

Plasmid profiles is one of the several useful methods for determining the relatedness or unrelatedness of bacterial strains that contain plasmid DNA. A large number of plasmids had been detected in E.coli as well as a large number of other bacterial species and their role in antibiotic resistance and other variable characters has been well established. The occurrence of multiple antibiotic resistances has also been shown to be due to a greater genetic mobilization of the antibiotic resistance genes carried by the plasmids (Gaddad and Shivannavar, 2011). In fact, plasmid profiles of the isolates are generally a useful tool for obtaining knowledge about resistance of the isolates to the antimicrobial substances and transfer of a plasmid among closely related isolates from different sources. Our results showed the high presence of virulence factors and multiple antibiotic-resistant properties among E.coli serotypes that were isolated from chicken meat samples (Momtaz and amshidi, 2013).

In conclusion there is an increase in detection of EHEC non O157. As well as there is an increase in antimicrobial resistance among the examined EHEC non $\mathrm{O} 157$ so paying attention to this group of E.coli is required to avoid the risk to human. To the authors' knowledge, excessive prescribing, crowding and poor sanitation are the primary factors responsible for the high antibiotic resistance in E.coli isolated from chicken meat. The sanitation conditions, especially in poultry slaughter houses and supermarkets could help to reduce the contamination rate of poultry meat. Finally, to prevent antibiotic resistance in bacteria, we have to prescribe antibiotics more cautiously in animals and periodically use different antibiotics.

\section{REFERENCE}

Armstrong, G.L.; Hollingsworth, J. and Morris, J.G. (1996): Emerging food borne pathogens: Escherichia coli O157:H7 as a model of entry of a new pathogen into the food supply of the developed world. Epidemiol. Rev. 18: 29-50.

Bauer, A.W.; Kirby, W.M.; Sherris, J.C. and Turck, M. (1966): Antibiotic susceptibility testing by a standardized single disc method. Am. J. Clin. Pathol. 45, 493496.

Bettelheim, K.A. (1996): Enterohaemorrhagic Escherichia coli-a review. Int. Food Hyg. 7: $5-9$.

Blanco, J.E.; Blanco, M.; Alonso, M.P.; Mora, A.; Dahbi, G.; Coira, M.A. and Blanco, J. (2004): Serotypes, virulence genes and intimin types of Shiga toxin (verotoxin)-producing Escherichia coli isolates from human patients: Prevalence in Lugo (Spain) from 1992 through 1999, J. Clin. Microbiol. 42, 311-319

Blanco, J.; Blanco, M.; Blanco, J.E.; Mora, A.; Alonso, M.P.; González, E.A. and Bernárdez, M.I. (2001): Epidemiology of verocytotoxigenic Escherichia coli (VTEC) in ruminants, in: G. Duffy, P. Garvey, D. McDowell (Eds.), Verocytotoxigenic Escherichia coli, Food and Nutrition Press Inc., Trumbull, USA, pp. 113-148.

Blanco, J.; Blanco, M.; Blanco, J.E.; Mora, A.; González, E.A.; Bernárdez, M.I.; Alonso, M.P.; Coira, A.; Rodríguez, A.; Rey, J.; Alonso, J.M. and Usera, M.A. (2003): Verotoxin-producing Escherichia coli in Spain: Prevalence, serotypes, and virulence genes of O157:H7 and non-O157 STEC in ruminants, raw beef products, and humans, Exp. Biol. Med. 228, 345-351.

Braoudaki, M. and Hilton, A.C. (2003):5th Int. Symp. Shiga toxin (verocytotoxin)-producing Escherichia coli infections, Edinburgh, UK, abstract P99, p. 128, 
Boerlin, P.; McEwen, S.A.; Boerlin-Petzold, F.; Wilson, J.B.; Johnson, R.P. and Gyles, C.L. (1999): Associations between virulence factors of Shiga toxin-producing Escherichia coli and disease in humans. J. Clin. Microbiol. 37:497-503.

Clark, N.C.; Olsvik, Ø.; Swenson, J.M.; Spiegel, C.A. and Tenover, F.C. (1999): Detection of a streptomycin/ spectinomycin adenylyl transferase gene $(\operatorname{aad} \mathrm{A})$ in Enterococcus faecalis. Antimicrob. Agents Chemother. 43, 157-160.

Clinicaland Laboratory Standards Institute (CLSI) (2011): Performance standards for antimicrobial susceptibility testing; twentyfirst informational supplement, CLSI document M100-S21, Wayne, PA, USA, 31, 42-46.

Colom, K.; Perez, J.; Alonso, R.; Fernandezaranguiz, A.; Larina, E. and Cisterna, R. (2003): Simple and reliable multiplex PCR assay for detection of blaTEM, bla (SHV) and blaOXA-1 genes in Enterobacteriaceae. FEMS Microbiol. Lett., 223, 147-151.

Dipineto, L.; Santaniello, A.; Fontanella, M.; Lagos, K.; Fioretti, A. and Menna, L.F. (2006): Presence of shiga toxin - producing E.coli O157:H7 in living layer hens. Letters in applied microbiology, 43(3): 293-295.

Eid, S.E.A. and Erfan, A.M. (2013): Characterization of E.coli associated with high mortality of poultry flocks. Assiut Vet. Med. J., 59, 51-61.

El Oksh, A.S.A. (2014): Molecular studies on virulence and antibiotic resistance genes of E.coli isolated from different sources. Thesis Submitted to Fac. of Vet. Med., Zagazig University.

Ewers, C.; Li, G.; Wilking, H.; Kiessling, S.; Alt, K.; Antao, E.M.; Laturnus, C.; Diehl, I.; Glodde, S.; Homeier, T.; Bohnke, U.; Steinruck, H.; Philipp, H.C. and Wieler, L.H. (2007): Avian pathogenic, uropathogenic and newborn meningitis-causing E. coli: How closely related are they?. Int. J. Med. Microbiol., 297, 163176.

Farina, C.A.; Goglio, G.; Conedera, F.; Minelli, A. and Caprioli (1996): Antimicrobial susceptibility of Escherichia coli O157 and other enterohemorrhagic Escherichia coli isolated in Italy, Eur. J. Clin. Microbiol. Infect. Dis. 15, 351-353.

Friedrich, A.W.; Bielaszewska, M.; Zhang, W.; Pulz, M.; Kuczuis, T.; Ammon, A. and Karch, H. (2002): Escherichia coli harboring Shiga toxin 2 gene variants: frequency and association with clinical symptoms. J. Infect. Dis. 185:7484.

Gaddad, S.M. and Shivannavar, C.T. (2011): Detection Of Shiga Toxin Genes (Stx1 \&Stx2) And Molecular Characterization of ShigaToxigenic Escherichia Coli Isolated From
Diverse Sources In Gulbarga Region, India Kesava Naidu G.1, Rajendra Goud. N2, Pharmacophore, Vol. 2 (5), 253-265, ISSN 2229-5402.

Galland, J.C.; Hyatt, D.R.; Crupper, S.S. and Acheson, D.W. (2001): Prevalence, antibiotic susceptibility, and diversity of Escherichia coli $\mathrm{O} 157: \mathrm{H} 7$ isolates from a longitudinal study of beef cattle feedlots, Appl. Environ. Microbiol.67, 1619-1627.

Gyles, C.L. (2006): Shiga toxin-producing Escherichia coli: a review. J. Anim. Sci. 85:45-62

Hedican, E.B.; Medus, C.; Besser, J.M.; Juni, B.A.; Koziol, B.; Taylor, C. and Smith, K.E. (2009):Characteristics of O157 versus nonO157 Shiga toxin-producing Escherichia coli infections in Minnesota, 2000-2006.Clin. Infect. Dis. 49:358-364.

Horii, T.S.; Barua, T.K.; Kasugai, S.K.; Sato, K.; Shibayama, S.I. and Ohta, M. (1998): Heterogeneity of phenotypic and genotypic traits including organic-acid resistance in Escherichia coli O157 isolates, Microbiol. Immunol. 42, 871-874.

Kerrn, M.B.; Klemmensen, T.; Frimodtmollr, N. and Espersen, F. (2002): Susceptibility of Danish E. coli strains isolated from urinary tract infections and bacteraemia and distribution of sul genes conferring sulphonamide resistance. J. Antimicrob. Chemother. 50, 513-516.

Khan, A.; Das, S.C.; Ramamurthy, T.; Sikdar, A.; Khanam, J.; Yamasaki, S.; Takeda, Y. and Balakrish, G.N. (2002): Antibiotic ressistance, virulence gene, and molecular profiles of Shiga toxin-producing Escherichia coli isolates from diverse sources in Calcutta, India, J. Clin. Microbiol.40, 2009-2015.

Kilic, A.; Ertafi, H.B.; Muz, A.; Ozbey, G. and Kalender, H. (2007): Detection of the eaeA gene in Escherichia coli from chickens by polymerase chain reaction. Turk. J. Vet. Anim. Sci. 31:215-218.

Kim, T.E.; Jeong, Y.W.; Cho, S.H.; Kim, S.J. and Kwon, H.J. (2007): Chronological study of antibiotic resistances and their relevant genes in Korean avian pathogenic E.coli isolates. J. Clin. Microbiol, 45, 3309-3315.

Law, D. (2000): Virulence factors of Escherichia coli O157 and other Shiga toxin- producing E. coli. J. Appl. Microbiol. 88:729-745.

Lee, G.Y.; Jang, H.I.; Hwang, I.G. and Rhee, M.S. (2009): Prevalence and classification of pathogenic Escherichia coli isolated from fresh beef, poultry, and pork in Korea. Int. J. Food Microbiol. 134:196-200.

Lima-filho, J.V.; Martins, L.V.; Nascimenta, D.C.; Ventura, R.F.; Batista, J.E.; Silva, A.F.; Ralph M.T.; Vaz, R.V.; Rabello, C.B.; Sil, V.A.; Ide, M. and Evencio-neto, J. (2013): Zoonotic potential of multidrugresistant 
extraintestinalpathogenic $E$. coli obtained from healthy poultry carcasses in Salvador, Brazil. Braz. J. Infect. Dis., 17, 54-61.

Lukásová, J.; Abraham, B. and Cupáková, S. (2004): Occurrence of Escherichia coli 0157 in raw material and food in Czech Republic. J. Vet. Med. B Infect. Dis. Vet. Public Health 51:7781

Lyhs, U.; Ikonen, L.; Pohjanirta, T.; Raninen, K.; Perko-Makela, P. and Pelkonen, S. (2012): Extraintestinal pathogenic E.coli in poultry meat products on the Finnish retail market. Acta Vet. Scand., 54:64.

Magwedere, K.; Dang, H.A.; Mills, E.W.; Cutter, C.N.; Roberts, E.L. and DebRoy, C. (2013): Incidence of Shiga toxin-producing Escherichia coli strains in beef, pork, chicken, deer, boar, bison, and rabbit retail meat. Journal of Veterinary Diagnostic Investigation 25(2) 254-258

Momtaz, H. and Jamshidi, A. (2013): Shiga toxinproducing Escherichia coli isolated from chicken meat in Iran: Serogroups, virulence factors, and antimicrobial resistance properties, Poultry Science Association Inc.

Peer, F.U.; Ansari, M.; Gani, I.A. and Willayat, M.M. (2013): Serotyping and antibiotic sensitivity patterns of E.coli isolates obtained from broiler chicks in Kashmir Valley, India. Adv. Anim. Vet. Sci., 1(2):75-76.

Piva, I.C.; Pereira, A.L.; Ferraz, L.R.; Silva, R.S.N.; Vieira, A.C.; Blanco, J.E.; Blanco, M.; Blanco, J. and Giugliano, L.G. (2003): Virulence markers of enteroaggregative E.coli isolated from children and adults with diarrhea in Brasilia, Brazil. J. of Clinical microbiology, pp. 1827-1832.

O'Brien, A.D. and Holmes, R.K. (1987): Shiga and Shiga-like toxins. Microbiol. Rev. 51: 206-220.

Sahilah, A.M.; Aishaha, N.H.; Noraida, I. and Azuhairi, A.A. (2010): Detection of shiga toxin 1 and2 (stx1 and stx2) genes in Escherichia coli $\mathrm{O} 157: \mathrm{H} 7$ isolates from Retail beef in Malaysia by multiplex polymerase chain reaction. Sains Malaysiana, 39(1): 57-63.

Sambrook, J.; Fritscgh, E.F. and Meniates, T. (1989): Molecular Cloning: A laboratory manual, vol.
1. Cold Spring Harbor Laboratory press, New York.

Santos, M.M.; Alcantara, A.C.M.; Percmanis, S.; Campos, A. and Santana, A.P. (2014): Antimicrobial resistance of bacterial strains isolated from avian cellulitis. Rev. Bras. Cienc. Avic. 16, 13-18.

Schmidt, H.; Beutin, L. and Karch, H. (1995): Molecular analysis of the plasmid-encoded hemolysin of Escherichia coli 0157: H7 strain EDL 933. Infect Immun 63, 1055-1061.

Schmidt, H.; Plaschke, B.; Franke, S.; Russman, H.; Schwarzkopf, A.; Heesemann, J. and Karch, $H$. (1994): Differentiation in virulence patterns of Escherichia coli possessing eae genes. Med. Microbiol. Immunol. 183:23-31.

Schroeder, C.M.; Zhao, C.; DebRoy, C.; Torcolini, J.; Zhao, S.; White, D.G.; Wagner, D.D.; McDermott, P.F.; Walker, R.D. and Meng, J. (2002): Antimicrobial resistance of Escherichia coli $\mathrm{O} 157$ isolated from humans, cattle, swine, and food, Appl. Environ. Microbiol.68, 576-581.

Vidal, M.; Kruger, E.; Uran, C.D. and Vidal, R. (2005): Single multiplex PCR assay to identify stimulatingly the six categories of diarrheagenic E.coli associated with enteric infections. J. Clin. Microbiol., 43: 5362-5365.

Witte, W. (1998): Medical consequences of antibiotic use in agriculture, Science 279, 996-997.

Wong, C.S.; Jelacic, S.; Habeeb, R.L.; Watkins, S.L. and Tarr, P.I. (2000): The risk of hemolyticuremic syndrome after antibiotic treatment of Escherichia coli O157:H7 infections, New Engl. J. Med. 342, 1930-1936.

Xia, X.; Meng, J.; Mcdermott, P.F.; Ayers, S. and Zhao, S. (2010): Presence characterization of shiga toxin- producting E.coli and other potentially diarrheagnic E.coli strains in retial meats. Appl. Environ. Microbiol., 76:17091717.

Zhang, X.; McDaniel, A.D.; Wolf, L.E.; Keusch, G.T.; Waldor, M.K. and Acheson, D.W. (2000): Quinolone antibiotics induce Shiga toxinencoding bacteriophages, toxin production, and death in mice, J. Infect. Dis. 181, 664670 . 


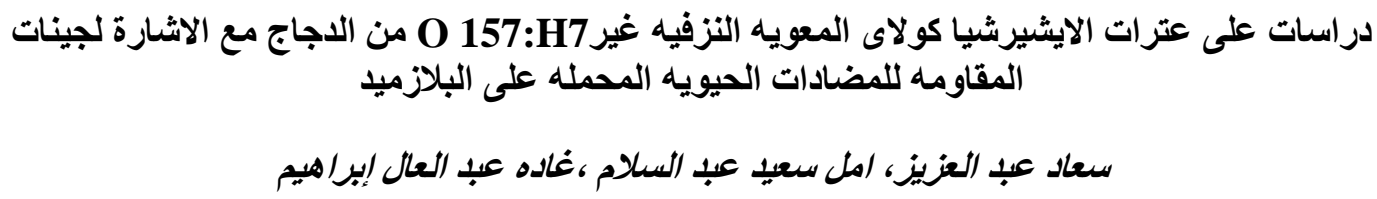

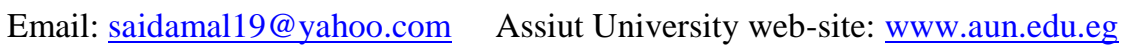

تعتبر الايثبرشياكو لاى المنتجه للسموم هي الأكثر أهمية والتى برزت في الآونة الأخيرة والمسبيه للامر اض المئه المعديه التى تنقلها

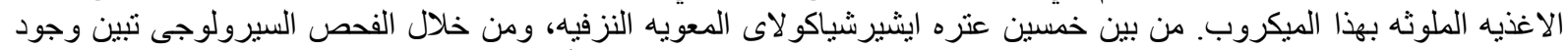

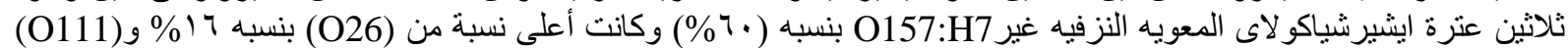

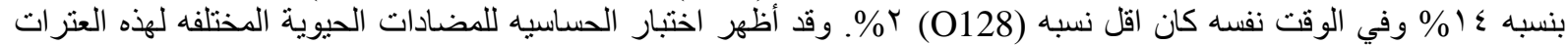

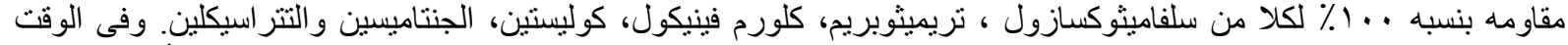

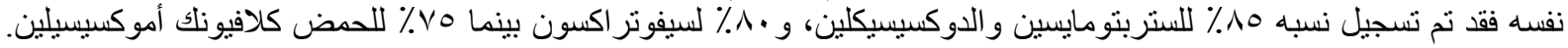

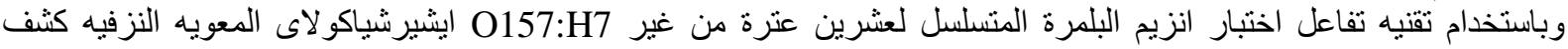

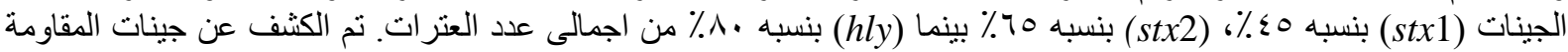

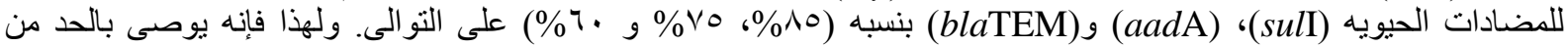
الاستخدام المفرط للمضادات الحيوية في مجال المعالجات البيطريه و المتابعه الدوريه لاستخدام المضادات المات الحيوية المختلفة حتى يمكن التغلب على مشكلة زيادة المقاومة الميكروبيه. 